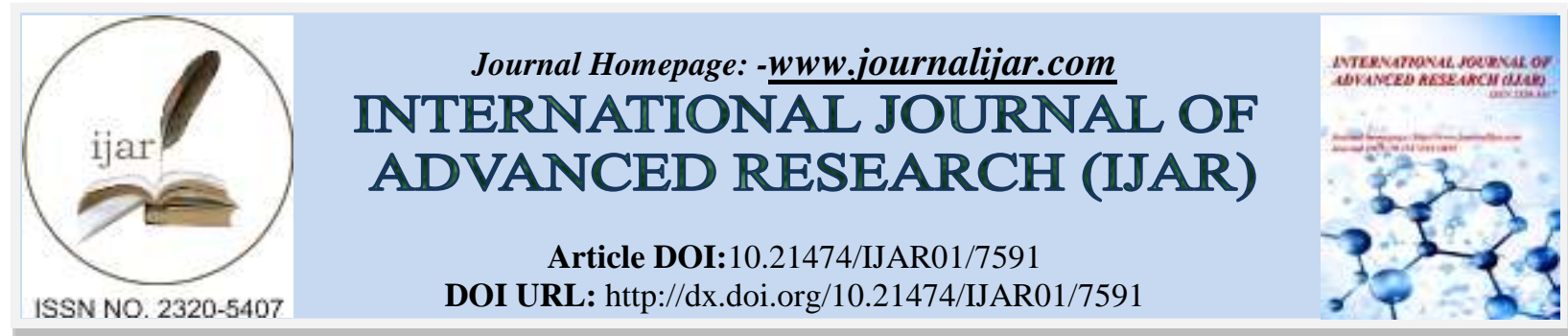

RESEARCH ARTICLE

\title{
RECONSTRUCTION OF SAVING FINANCIAL STATE LOSSES IN HANDLING CRIMINAL ACTION IN INDONESIA THROUGH JUSTICE-VALUE BASED.
}

1. PhD Students of Faculty of Law.

\section{Bastian Lubis and Andhika Yuli Rimbawan.}

2. Islamic University of Sultan Agung, Semarang, Indonesia.

\section{Manuscript Info}

Manuscript History

Received: 18 June 2018

Final Accepted: 20 July 2018

Published: August 2018

\section{Keywords:-}

financial state loses, corruption cases, management, justice-value based.

\section{Abstract}

In carrying out the management of this financial state, it should be noted that although there have been several laws and regulations regulating the management of financial state, both at the central level and up to the level of Province, Regency or City even now to the village level throughout Indonesia, there were still many irregularities found by individual state finance managers. This particular matter will cause loss of financial state. The handling of criminal acts, including corruption, is currently emphasizing the retributive justice approach, which I think we need perform a new approach called restorative justice. The retributive justice approach putting more criminal sanctions (primum remidium) has experienced mayfailures in both preventing and eradicating corruption. As written in the applied corruption rules, the goal addressed by the law makers is how law enforcement officers work optimally to recover losses to the state. As the failure to prevent and eradicate corruption by using retributive justice approach, a new approach is urgently needed, namely the restorative justice. Besides Restorative justice approach has a function to prevent and eradicate corruption, this approach can be also used as a means of optimizing the return of losses to the state and saving costs incurred in managing a corruption case. In this case, the rescue of financial state losses in the handling of corruption cases in Indonesia is indispensable, by looking at the related laws which are not yet effective, which actually triggered more harm to the state in terms of financing the process of implementing law enforcement against corruption cases. Therefore, the existing ralated laws related to corruption eradication, the commission of eradicating corruption and state finances must be reconstructed regarding how deficiencies need to be improved in terms of legal reconstruction and reconstruction of values.

Copy Right, IJAR, 2018,. All rights reserved.

\section{Introduction:-}

In achieving the goals of a country, it will always be associated with financial state as a form of financing for state government administrators carried out by state administrators. Therefore, financial state is needed in a government environment in order to run the wheels of the economy which are mutually sustainable, so that the goals of the 
country can be achieved and not just the goals. Therefore, as a rule of written law in the matter of administering state finances must be in accordance with the frame of the 1945 Constitution of the Republic of Indonesia. There are at least three conditions, so that the law can play a role in pussing up the national economy, which is law must be able to create predictability, stability, and fairness. ${ }^{1}$

Financial state is all state rights and obligations that can be measured by money, as well as everything in the form of eithr money or goods, that can be used as state property due to the implementation of these rights and obligations. . ${ }^{2}$

All activities related to financial state will certainly be requested for financial statements and accountability in accordance with Law Number 15 of 2004 concerning Inspection of Management and Responsibility of State Finance and Law Number 17 of 2003 concerning State Finance. In its implementation, it is based on Law Number 15 of 2006 concerning the State Audit Board and other regulations relating to state finances. In essence, Law Number 17 of 2003 concerning State Finance regulates budget politics that has been prepared in accordance with the vision and mission of the government, Law Number 1 of 2004 concerning State Treasury regulates administrative administration operations until the preparation of State Finance reports, Law Law Number 15 of 2004 concerning Examination of the Management and Responsibility of State Finance regulates the accountability of State Finance after use.

All activities related to financial state will certainly be requested for financial statements and accountability in accordance with Law Number 15 of 2004 concerning Inspection of Management and Responsibility of financial state and Law Number 17 of 2003 concerning financial state. In its implementation, it is based on Law Number 15 of 2006 concerning the State Audit Board and other regulations relating to financial state. In this point, law Number 17 of 2003 concerning financial state regulates budget politics that has been prepared in accordance with the vision and mission of the government, Law Number 1 of 2004 concerning State Treasury regulates administrative administration operations until the preparation of financial state reports, Law Law Number 15 of 2004 concerning Examination of the Management and Responsibility of State Finance regulates the accountability of financial state after use.

It should be noted that the current issues and the many legislative products that often cause differences in views and points of view both in the academic realm and in the practice of law enforcement, and the need for comprehensive knowledge and understanding of law enforcement officers, so that there is a common mindset and movement between investigators, public prosecutors and judges in handling cases of corruption. Therefore, it is necessary to have a common perception in terms of handling corruption, which so far has not considered the aspect of saving state losses with the smallest possible funding from law enforcers.

In handling corruption by law enforcement performed by the officers of the Corruption Eradication Commission (KPK), Prosecutor's Office, Polices, either by on-the spot operation or through investigation or follow-up of reports or findings by the Supreme Audit Agency (BPK) or the Financial and Development Supervisory Agency (BPKP) in one region, starting from the level of investigation then moved to the level of investigation, examination of suspects, examination of witnesses, up to the delegation to the court to be used to spend very large operational funds. Not to mention that a court decision will be sentenced to convict the defendant, who must place the defendant to serve a period of detention in the penitentiary in accordance with the court's decision. The operational costs are very large from the beginning of the investigation to the defendant in a court verdict to serve a sentence in the Penal Institution until the completion of the sentence. There are several examples of cases where the state loss rate for corruption acts is greater than the case handling costs than the state losses that occur. In the imposition of fines or substitute money, it has not been able to save the state losses that are returned to the state treasury and not yet based on the value of justice. This occurs because the burden of operational costs for handling the case is greater than the return of state losse.

The handling of criminal acts, including corruption, is currently emphasizing the retributive justice approach. In the retributive justice approach, that puts forward criminal sanctions (primum remidium), it has experienced various failures in preventing and eradicating corruption. In the applicable Corruption Act if it is examined more deeply, the

${ }^{1}$ Leonard J. Theberge, Law and Economic Development, Journal of International Law and Policy. Vol. 9 (1980). p.232.

${ }^{2}$ Chapter1 Point 1 National regulations Number 17 year 2003 about Financial state. 
goal to be addressed by the legislators is how law enforcement officers work optimally to recover losses to the state. For the failure to prevent and eradicate corruption by using retributive justice approach, a new approach is needed, namely restorative justice. Restorative justice approach in addition is functioned to prevent and eradicate corruption, this approach can be used as a means of optimizing the return of losses to the state and saving costs incurred in managing a corruption case. ${ }^{3}$

For this reason, we need such formulation that is able to save the budget costs incurred by the government, which in this case is handling corruption. In addition, it is necessary to apply optimization in the return of state losses by law enforcement officials as well as legislators and parties related to handling corruption. At this point, the writer can formulate an ideal formulation in handling corruption by minimizing budget expenditure from the state which is financed from the people's tax for handling a corruption act and efforts to recover state losses into the state treasury so that the law enforcement paradigm in Indonesia will not be based on enforcement but rather on a preventive approach, so that the budget for handling criminal acts of corruption is reduced. This also relates to the legislation concerning corruption which is now in force. Indeed, there needs to be a change that must be made, so that it requires the cooperation of the parties concerned. In this case the author focuses on reviewing corruption cases that cause state financial state loses.

\section{Discussion:-}

\section{Elements of State Losses Due to Corruption}

State loss is different from the loss in the sense of the company / commercial world, but a loss that occurs because of an act (unlawful act). Financial state losses can occur in 2 stages, namely at the stage of the Fund will enter the State Treasury and at the stage of funds will come out of the State treasury. ${ }^{4}$ At the stage of funds that will enter the state treasury the losses can occur through, for example, tax conspiracy, conspiracy to pay criminal penalties, conspiracy to implement additional crimes (returning state losses) and smuggling. Whereas at the stage of the funds will come out of the state treasurylosses occur due to: mark up, Corruption, implementation of activities that are not in accordance with the program and others. There are several ways in which state financial losses occur according to Yunus Husein, namely state losses related to various transactions: transactions of goods and services, transactions related to accounts payable, and transactions related to costs and incomes. ${ }^{5}$

Financial state losses in corruption are formulated in Article 2 paragraph (1) and Article 3 of the Corruption Act, stated "Every person who unlawfully acts to enrich himself or another person or a corporation that can harm the state's finances or the country's economy... ". As for the elements of corruption concerning the loss of state finances as stated in Article 2 paragraph (1), the Act enriches its intention to do anything with the intention of increasing wealth, such as taking, transferring books, depositing with interest, etc. " Against the law", against the law here is defined both formally and materially, which can harm the state's finances or the country's economy. The word can show that the offense in Article 2 paragraph (1) of the Corruption Act, is a formal offense meaning that the offense has been deemed complete if the elements of the action are formulated without any consequences. The element against the law is not only against the laws and regulations but also if the act is not in accordance with the sense of justice or norms of social life in society, then the act can be punished. ${ }^{7}$

Confusion also occurred in the recording of elements of "financial state losses". Occasionally in judicial practice it has been proven that the element of "financial state loss", but the element of enriching oneself or other people or a corporation (Article 2 paragraph (1)), or the element of "benefiting oneself or others or a corporation" is not proven. This was used as an excuse to release suspects of corruption. Such errors in juridical construction seem to hamper the process of law enforcement. It should be proven that the element of state loss means that there is no money or

${ }^{3}$ Fadil Zumhana, Restorative Justice Sebagai Primum Remedium in effort to return financial state loses, A Dissertationi, University of Airlangga, Surabaya, 2015, p 9.

${ }^{4}$ Anthony Kennedy, An Evaluation of the Recovery of Criminal Proceeds in the United Kingdom, 10(1) Journal of Money Laundering Control, 2007, p 37.

${ }^{5}$ YunusHusein, Financial loses onTipikor, Seputar Indonesia 28 May 2008, p 7.

${ }^{6}$ Marwan Effendy, Court R.I. PosisidanFungsinyadariPerspektifHukum, PT. GramediaPustakaUtama, Jakarta, 2005, p 81.

${ }^{7}$ AdamiChazawi, HukumPembuktianTindakPidanaKorupsi UU No.31 year 1999 transformed into UU No.20 Tahun 2001, PT. Alumni, Bandung, 2008, p 298. 
state assets left. This ensures that the suspect has enriched himself or another person or a corporation, or the suspect has benefited himself or another person or a corporation, with money or state assets that have been proven lost. Thus, it is proven that the element of state financial loss in a trial, it can be said that the element of enriching yourself or another person or a corporation, or has benefited yourself or someone else or a corporation, has also been proven. If not, then illogical juridical construction will occur. Where is the money or wealth of the lost country.

\section{Form of State Financial Loss Rescue:-}

According to the laws of the Corruption Eradication Act, stating that the mechanism for returning state losses can be donethrough two legal instruments, namely criminal and civil.

\section{Criminal Instruments:-}

The criminal instrument is carried out by the investigator by confiscating the property of the perpetrator. Foreclosure actions pursuant to Article 1 of the Criminal Procedure Code, seizure ${ }^{8}$ is "a series of actions by investigators to take over or keep under their movable or immovable authority, tangible or intangible objects for the purpose of proof in investigation, prosecution and trial". The purpose of confiscation is for the purpose of proof, especially intended as evidence in court. Without evidence, the case cannot be filed before a court. Therefore, this can be used as an effort to recover state losses through criminal instruments because the Prosecutor is then demanded to be seized by the judge.

The recovery of financial state losses is also regulated in the United Nations Convention Againt Corruption / UNCAC which has been ratified by Law Number 7 of 2006 concerning the Anti-Corruption Convention (KAK Law). In the KAK Law, return on assets can be carried out through criminal channels (indirect asset recovery through criminal recovery) and civil channels (direct asset recovery through civil recovery). Assets of direct recovery through civil recovery are carried out through civil lawsuits against owners of assets that are allegedly originating from criminal acts of corruption, and these assets are placed in other countries. ${ }^{9}$ Romli Atmasasmita mentioned specifically that the criminal law route is an indirect asset recovery, so the process of returning assets is usually through 4 (four) stages, namely: ${ }^{10}$

1. Assets tracking with the aim of identifying assets, proof of asset ownership, location of asset storage in the capacity of the relationship with the offense carried out;

2. Freezing or appropriation of assets where according to Chapter I Article 2 letter f, saying that the AntiCorruption Convention Act of this aspect is determined to include a temporary ban on transferring, converting, disposing or transferring property or temporarily bearing the burden and responsibility of managing and maintaining and supervising wealth based on a court decision or stipulation from other competent authorities;

3. Confiscation of assets which according to Chapter I Article 2 letter $\mathrm{g}$ of the Anti-Corruption Convention Law, which is defined as the revocation of wealth for eternity based on the determination of a court or other competent authority;

4. Returning and submitting assets to the country victims.

The principle of asset return is regulated in the provisions of Article 51 of the Anti-Corruption Convention Act which states that: the return of assets according to this chapter is a fundamental principle of this convention, and the participating states must provide mutual cooperation and assistance as widely as possible in this matter.

\section{Civil Instruments:-}

One of factors triggering the involvement of civil instruments in the Corruption Eradication Act (PTPK Law), due to the development of problems in society that are now increasingly complex, such as the example of the case above concerning the problem of saving state financial losses due to corruption which the defendant died this. The thought of incorporating a civil mechanism into the PTPK Law explicitly shows that the criminal mechanism in returning

\footnotetext{
${ }^{8}$ AdamiChazawi, HukumPembuktianTindakPidanaKorupsi UU No.31 year 1999 transformed to UU No.20 year 2001, PT. Alumni, Bandung, 2008, p 298.

${ }^{9}$ Stefan D. Cassela, The Case for Civil Forfeiture: Why In Rem Proceddings are an Essential Tool for Recovering the Proceeds of Crime, 2007, p 2.

${ }^{10}$ RomliAtmasasmita, PengembalianAsetKorupsi: MasukanKonvensi International Anti Korupsi, Seputar Indonesia, August 13 2007, p 7.
} 
assets is not enough. Civil lawsuits are thus intended to maximize the return of financial state because criminal efforts do not always succeed in returning the entire financial state loss. Efforts to recover financial state finances (asset recovery) due to corruption crimes using civil instruments are treated by Prosecutors as State Attorney Attorney (JPN). For state assets in this case, it is equated with state assets whose rights are taken over by one or more or a corporation that can be made possible through the granting of corruption during state duties. JPN or the aggrieved institution carries out a civil suit against the corruption perpetrator (suspect, defendant or convicted person or his heir if the convict dies).

In the authority and duty of prosecutors as state lawyers in saving financial state and state assets, the prosecutor will act both as a proposer and also as a defendant dealing with various parties who have taken financial state and or state assets as a result of corruption or on the basis of civil losses.

\section{Penalty or State Loss Returns:-}

In our criminal law, there is a type of criminal offense that eliminates the freedom of movement from the convict, namely imprisonment. The purpose of imprisonment itself according to Dr. Saharjdo, SH in his acceptance speech of doctor honoris causa in law from the University of Indonesia on July 5, 1963 was as follows: "Besides causing suffering to the convicted person because of the loss of freedom of movement, guiding the convicted person to repent, educating him to become a member of the Indonesian socialist community which is useful, briefly criminal objectives are social ". 11

The implementation of criminal prosecutions in particular the implementation of imprisonment cannot be separated from the criminal law enforcement system in the sense of an integrated criminal justice system and the administration of criminal justice system. In an open system of every component of law enforcement in collaboration with a criminal justice systemic approach and the implementing component of imprisonment, the occupation is part of the instrument that deals with the conversion process in the form of human outputs of citizens who obey the law. ${ }^{12}$ Basically there are several stages or even the whole stage of criminal justice that is realized or not realized is a degradation of humans where a person's individuality is gradually taken away, as a result of the length of human intervention of criminal law functionaries. Humans who violate criminal law are dealing with many people who play a role in criminal justice from the beginning to the end, and in turn of executing imprisonment officers (prison officials) dealing with convicted people who have suffered from this degradation.

In this case, the criminal act of corruption is a criminal act regulated by a separate law, namely Law No. 31 of 1999 jo. Law No. 20 of 2001 concerning Eradication of Corruption Crimes. So that the criminal act of corruption is a special crime because it is regulated outside the Criminal Code (KUHP). Thus the criminal penalties regulated in the Corruption Act are addressed to special people or those related to special acts. Against this particularity, the most important thing to know is the existence of irregularities in the Corruption Law from the general provisions, the rest that do not deviate by themselves remain valid. ${ }^{13}$ It can be seen in the previous description that the eradication of criminal acts of corruption still uses the perspective of criminal prosecution rather than using the perspective of financial state losses. This is striking at the time of giving criminal sanctions for corruptors where law enforcement (judges and prosecutors) are more in pursuit of criminal prosecution, which is to imprison the perpetrator.

It should keep in mind that to know that sanctions in criminal law according to the modern view are the prevention (deterrence). ${ }^{14}$ The legislator intends that other people do not commit criminal acts (bad deeds) by frightening or threatening with criminal sanctions. That way people are reluctant to commit a criminal act with a note that the criminal sanctions are heavier than the results of their criminal actions. The question arises whether the sanctions imposed on corruptors can deter him and prevent others from doing the same thing. If the adherents of the positivism paradigm say the Indonesian legal system is effective enough to ensure corruptors, this could be true. But the question is why are there many corruption cases in Indonesia ?, which means that certain people do not feel

\footnotetext{
${ }^{11}$ Sahardjo, PohonBeringinPengayoman, official speech at Ceremonial for Doctorate Degree, Jakarta, 1963.

${ }^{12}$ BambangPurnomo, KapitaSelektaHukumPidana, Liberty Yogyakarta, 1988, p 34.

${ }^{13}$ AndiHamzah, PemberantasanKorupsiDitinjau Dari HukumPidana, Study Center ofCivil Law of Usakti, Jakarta, 2002, p 1.

${ }^{14}$ JimlyAsshiddiqqiedan M. Ali Safa'at, Teori Hans KelsenTentangHukum, Press of Konstitusi, Jakarta, 2012 , p 46
} 
afraid by the strong threat of criminal sanctions in the legislation. Then what is wrong or lack of existing law to eradicate corruption. This balance is in line with the statement of Prof Satjipto Rahardjo namely: ${ }^{15}$

"The belief in the law is decreasing due to the poor performance of the law, in the past (the new order era) law increasingly shifted to become a political medium for maintaining power, whereas in the reform era it showed the failure of law to eradicate corruption, raising questions' what is wrong with our law ? 'and' what and how to overcome it? '

Criminal law in order to eradicate criminal acts of corruption can be considered a failure. This is evidenced by the fact that corruptors are not afraid of criminal sanctions for imprisonment (body punishment), because the criminal sanctions (imprisonment, fines, substitution money) are considered light compared to the money obtained from corruption as illustrated in the introduction above. When corruptors are sentenced to be guilty by court decisions, considering many phenomena of corruption cases in Indonesia where these convicts are not deterred by the punishment they receive. With the proceeds of corruption, the corruptors can bribe officers in the prison to provide luxury facilities for him in prison. Plus, this corruptor can still enjoy a lot of money after he completes his sentence process in a penitentiary.

Seeing this, the fact that the judicial process for corruptors requires a higher budget makes the need for other policies for the effectiveness and saving of the state budget in which in this case the state must consider matters that really need solutions to problems that tend to harm state finances. Related to the high cost of handling corruption, besides that when the convicted people have entered the detention phase, it is undeniable to add to the state budget expenditure costs in the Correctional Institution. In this case the importance of the act of returning financial state so that the losses caused by corruptors do not add to the suffering of the state or the people in terms of how much state money is lost or disbursed to deal with corruption cases in which the magnitude of the losses suffered. In the legal dimension of state administration, based on Article 1 number 22 of Law No. 1 of 2004 concerning State Treasury and Article 1 paragraph 15 of Law No. 15 of 2006 concerning the State Audit Board (BPK Law); the loss of financial state is defined as a lack of money, securities, and goods, which are real and certain in number as a result of unlawful acts whether intentional or negligent. Means that the loss is in the form of loss of money, securities, and goods within the scope of the definition of state finances as stipulated in Law No.17 of 2003 concerning State Finance, the BPK Law, and Law No. 31 of 1999 jo. UU no. 20 of 2001 (Corruption Act).

\section{Conclusion:-}

From the background of research that rescues the loss of financial states in handling corruption cases which is realized when a rule of three primary rules is the Law on eradicating corruption, the Law on the Corruption Eradication Commission and the Law on financial statecan be a basic reference for the implementation of law enforcement against corruption to be given a reconstruction of the value and reconstruction of the law in the form of changes and the addition of article points so that the objective for the effectiveness of financing through the state budget for the execution of corruption perpetrators can be achieved.

The Writer's brief biography:-

Bastian Lubis, S.E., MM, PhD student of Law Faculty at Sultan Agung Islamic University (UNISSULA), Semarang, Indonesia. Jl. Raya Kaligawe KM 4 Semarang, Central Java, Indonesia.

\footnotetext{
Books

${ }^{15}$ H. PrayitnoImanSantosa, PertanggungjawabanTindakPidanaKorupsi, Bandung, Alumni, 2015, p 62.
} 


\section{References:-}

1. Adami Chazawi, Hukum Pembuktian Tindak Pidana Korupsi UU No.31 year 1999 transformed to UU No.20 year 2001, PT. Alumni, Bandung, 2008.

2. Andi Hamzah, Pemberantasan Korupsi Ditinjau Dari Hukum Pidana, Study Center of Lawof Usakti, Jakarta, 2002.

3. Bambang Purnomo, Kapita Selekta Hukum Pidana, Liberty Yogyakarta, 1988.

4. Fadil Zumhana, Restorative Justice Sebagai Primum Remedium Dalam Upaya PengembalianKerugian Keuangan Negara, A Dissertation, University of Airlangga, Surabaya, 2015.

5. H. Prayitno Iman Santosa, Pertanggungjawaban Tindak Pidana Korupsi, Bandung, Alumnus, 2015.

6. Jimly Asshiddiqqie dan M. Ali Safa'at, Teori Hans Kelsen Tentang Hukum, Press of Konstitusi, Jakarta, 2012.

7. Marwan Effendy, Kejaksaan R.I. Posisi dan Fungsinya dari Perspektif Hukum, PT. Gramedia Pustaka Utama, Jakarta, 2005.

8. Romli Atmasasmita, Pengembalian Aset Korupsi: Masukan Konvensi International Anti Korupsi, Seputar Indonesia, August $13^{\text {th }} 2007$.

9. Yunus Husein, Kerugian Negara dalam Tipikor, Seputar Indonesia May, $28^{\text {th }} 2008$.

\section{National Laws}

10. Books of Law regarding Civil Laws

11. Laws of 17 year 2003 about financial states.

Journals

12. Anthony Kennedy, An Evaluation of the Recovery of Criminal Proceeds in the United Kingdom, 10(1) Journal of Money Laundering Control, 2007.

13. Leonard J. Theberge, Law and Economic Development, Journal of International Law and Policy. Vol. 91980.

14. Stefan D. Cassela, The Case for Civil Forfeiture: Why In Rem Proceddings are an Essential Tool for Recovering the Proceeds of Crime, 2007. 